\title{
Protein-bound polysaccharide-K reduces the proportion of regulatory $T$ cells in vitro and in vivo
}

\author{
RIEKO AOKI $^{1,2}$, HIROKO IIJIMA ${ }^{1}$, MARIKO KATO ${ }^{1}$, MOTOYUKI UCHIDA ${ }^{1}$, TSUTOMU WADA ${ }^{1}$, \\ MASATSUNE MURATA ${ }^{2}$, KENJI OGAWA ${ }^{3}$, YOSHIHIKO NARITAKA ${ }^{3}$ and KAZUHIKO YOSHIMATSU ${ }^{3}$ \\ ${ }^{1}$ Pharmaceuticals Division, Kureha Corporation, Tokyo; ${ }^{2}$ Department of Nutrition and Food Science, Ochanomizu University, \\ Tokyo; ${ }^{3}$ Department of Surgery, Tokyo Women's Medical University, Medical Center East, Tokyo, Japan
}

Received August 26, 2013; Accepted September 30, 2013

DOI: 10.3892/or.2013.2834

\begin{abstract}
Regulatory T cells (Tregs) play an important role in maintaining immunological tolerance. However, this mechanism is one of the major obstacles to overcome when attempting to improve antitumor immunity. Protein-bound polysaccharide-K (PSK) has been used clinically as an antitumor drug, and one of its antitumor mechanisms involves improvement of the tumor-induced immunosuppressive state. Therefore, we investigated whether PSK affects Tregs in vitro and in vivo. In the in vitro study, $\mathrm{CD} 4^{+} \mathrm{CD} 25^{-}$cells were separated from normal mouse spleen and cultured with or without PSK in the presence of TGF- $\beta$. Although TGF- $\beta$ induced $\mathrm{CD}^{+}{ }^{+} \mathrm{CD} 25^{+} \mathrm{Foxp}^{+}$Tregs, PSK reduced the proportion of TGF- $\beta$-induced Tregs. In the in vivo study, BALB/c mice were injected subcutaneously with methylcholanthreneinduced fibrosarcoma (Meth A) cells on day 0, and were administered PSK $(50 \mathrm{mg} / \mathrm{kg})$ intraperitoneally from day 1 , three times per week. After 4 weeks, the tumor volume, the proportion of Tregs and the $\mathrm{CD} 8^{+} /$Treg ratio in the spleen, plasma TGF- $\beta$ concentration, and IFN- $\gamma$ production by spleen cells were measured. PSK significantly reduced tumor growth, the proportion of Tregs in the spleen and the plasma TGF- $\beta$ concentration, and significantly increased the $\mathrm{CD} 8^{+} /$Treg ratio in the spleen and IFN- $\gamma$ production by spleen cells. The reduction of the TGF- $\beta$ concentration in blood by PSK appears to decrease the proportion of Tregs in lymphoid organs and to augment antitumor immunity.
\end{abstract}

\section{Introduction}

Cancer cells are recognized by the immune system as foreign objects, and are destroyed by immune cells (1)

Correspondence to: Dr Rieko Aoki, Pharmaceuticals Division, Kureha Corporation, 3-26-2 Hyakunin-cho, Shinjuku-ku, Tokyo 169-8503, Japan

E-mail: aokirieko@kureha.co.jp

Key words: protein-bound polysaccharide-K, regulatory $\mathrm{T}$ cells, transforming growth factor- $\beta$, methylcholanthrene-induced fibrosarcoma
However, cancer cells are known to evade the antitumor immune response by multiple immunosuppressive mechanisms, such as i) losing major histocompatibility complex (MHC) molecules so as to avoid recognition by immune cells (2), ii) producing immunosuppressive cytokines (3), and iii) inducing immunosuppressive cells including myeloid derived suppressor cells (MDSCs) (4) and regulatory T cells (Tregs) (5) to interfere with attack by other immune cells. In particular, MDSCs and Tregs have been focused on and studied recently as targets of cancer therapy.

Regulatory $\mathrm{T}$ cells are one of immune suppressor cells and play an important role in maintaining immunological tolerance. However, this mechanism is one of the main obstacles to overcome when attempting to improve antitumor immunity. In fact, the accumulation of Tregs in tumor tissues (6) and peripheral blood (7) is correlated with poor prognosis in patients with cancer. Recently, several studies have also reported the importance of a balance between immune effective cells and immune suppressor cells. For example, the $\mathrm{CD} 8^{+} \mathrm{T}$ cell/Treg ratio was found to be associated with overall survival time in patients with colorectal cancer (8). These studies, thus, show that Tregs are the major player in suppressing antitumor effects. Various methods to deplete Tregs have been evaluated in clinical trials (9-11). Previous studies have demonstrated that naïve $\mathrm{T}$ cells differentiate into Tregs in the presence of TGF- $\beta$ in the periphery $(12,13)$. Therefore, TGF- $\beta$ plays a critical role in the induction and maintenance of Tregs.

PSK is a protein-bound polysaccharide purified from the mycelium of Corious versicolor, and has been used in Japan as an adjuvant therapy for gastric and colorectal cancer in combination with chemotherapy, and as an adjuvant treatment for small cell lung cancer in combination with chemoradiotherapy. Various actions of protein-bound polysaccharide-K (PSK) have been reported, such as direct suppression of tumor growth (14) and induction of cytokine production $(15,16)$. PSK has also been reported to improve the immunosuppressive state of tumor-bearing hosts by suppressing TGF- $\beta$ activity in vitro (17) and in vivo (18).

We, therefore, hypothesized that PSK reduces Tregs through suppression of TGF- $\beta$ resulting in augmentation of antitumor immunity. In fact, a clinical trial previously reported that PSK reduces the proportion of Tregs in the peripheral 
blood of gastric cancer patients (19). However, the relationship between PSK and Tregs as well as the mechanism by which PSK reduces the proportion of Tregs remain unclear. In the present study, we investigated whether PSK affects Tregs in vitro and in vivo, and found that reduction of TGF- $\beta$ by PSK decreases the proportion of Tregs in the spleen and augments antitumor immunity.

\section{Materials and methods}

Mice. C57BL/6 and BALB/c female mice were purchased from Charles River Laboratories Japan, Inc. (Yokohama, Japan). All animals were maintained under a specific pathogenfree condition. BALB/c mice were used in experiments at 6 weeks of age. C57BL/6 mice were used from 6 weeks to 12 weeks of age. All animal experiments were performed under the Institutional Guidelines for Care and Use of Laboratory Animals (Kureha Corp., Tokyo, Japan). The experimental protocol was approved by the Ethics Committee on Animal Experiments of the Biomedical Research Laboratories of Kureha Corp., and the mice were handled in accordance with the guidelines of the committee.

Reagents. PSK (Kureha Corp.) was dissolved in sterilized physiological saline, and then diluted to appropriate concentrations for use in the in vivo and in vitro experiments. The anti-CD3e and anti-CD28 antibodies (BD Biosciences, Franklin Lakes, NJ, USA) were used in the in vitro assay. The anti-CD25 antibody produced by hybridoma PC61 (ATCC) was a rat IgG1 antibody. For in vivo administration, the anti-CD25 antibody (PC61) was used after purification from hybridoma ascites produced in SCID mice. The concentration of IgG was determined by the Rat IgG1 ELISA Quantitation kit (Bethyl Laboratories, Montgomery, TX, USA). The FITCanti-CD4 antibody (clone RM4-5; eBioscience, San Diego, CA, USA), APC-anti-CD25 antibody (clone PC61; eBioscience), PE-anti-Foxp3 antibody (clone FJK-16; eBioscience), and PerCP-anti-CD8a antibody (clone 53-6.7; BioLegend, San Diego, CA, USA) were used in the flow cytometry.

Regulatory $T$ cell conversion assay. Spleens from C57BL/6 mice were gently minced into single-cell suspensions in complete RPMI-1640 containing $10 \%$ fetal bovine serum (FBS) (BioWest, Nuaillé, France), and CD4 ${ }^{+} \mathrm{CD} 25^{-} \mathrm{T}$ cells were purified using MACS beads (Miltenyi Biotec, Bergisch Gladbach, Germany). The purity of the $\mathrm{CD} 4^{+} \mathrm{CD} 25^{-} \mathrm{T}$ cells was confirmed to be $>90 \%$ by flow cytometry. These cells were suspended in RPMI-1640 supplemented with $10 \%$ FBS, $1 \mathrm{mmol} / 1$ sodium pyruvate, $2 \mathrm{mmol} / \mathrm{l} \mathrm{L-glutamine}$, non-essential amino acids, $25 \mathrm{mmol} / 1$ HEPES buffer and $50 \mu \mathrm{mol} / 12$-mercaptoethanol. The cell suspension was adjusted to a density of $1 \times 10^{6}$ cells $/ \mathrm{ml}$ and used in the conversion assays.

For conversion to Tregs, $\mathrm{CD} 4{ }^{+} \mathrm{CD} 25^{-}$cells were cultured with $2 \mu \mathrm{g} / \mathrm{ml}$ of the anti-CD3 antibody and $2 \mu \mathrm{g} / \mathrm{ml}$ of the anti-CD28 antibody in the presence of $20 \mathrm{U} / \mathrm{ml}$ recombinant human IL-2 (PeproTech Inc., Rocky Hill, NJ, USA) and 2 ng/ml recombinant TGF- $\beta$ (R\&D Systems, Minneapolis, MN, USA) for 4 days in a 96 -well plate. After incubation, the proportions of Tregs were analyzed by a flow cytometer.
Depletion of Tregs. BALB/c mice were inoculated subcutaneously with $1 \times 10^{6}$ methylcholanthrene-induced fibrosarcoma (Meth A) cells on day 0. These mice were injected intraperitoneally with $500 \mu \mathrm{g}$ of the anti-CD25 antibody on days $1,7,14$ and 21 to selectively deplete $\mathrm{CD} 25^{+}$cells. Control mice were administered rat $\mathrm{IgG}$. Tumor size was measured using calipers twice a week.

Antitumor effect following administration of PSK in vivo. BALB/c mice were inoculated subcutaneously with $1 \times 10^{6}$ Meth A cells on day 0 . From day 1 , the mice received intraperitoneal injection of PSK $(50 \mathrm{mg} / \mathrm{kg}$ ) three times per week. Control mice were administered saline intraperitoneally. Tumor size was measured twice a week. After 4 weeks, all mice were euthanized, and the tumor weights were measured. The proportion of Tregs and the $\mathrm{CD}^{+}$cell-to-Treg cell $\left(\mathrm{CD}^{+} /\right.$Treg) ratio in the spleen, plasma TGF- $\beta$ concentration and IFN- $\gamma$ production by spleen cells were also measured.

Flow cytometry. The proportions of regulatory $\mathrm{T}$ cells were measured using a Mouse Regulatory $\mathrm{T}$ cell staining kit (eBioscience). In brief, the cells from the in vitro Treg conversion assay were stained with the FITC-anti-CD4 and APC-anti-CD25 antibodies, and then suspended in Fix/Perm buffer and incubated. The cells were washed with permeabilization buffer and stained with the anti-mouse Foxp3 antibody. After washing with permeabilization buffer, the cells were analyzed by a FACScalibur flow cytometer (BD Biosciences).

For the in vivo study, spleens from mice were minced into single-cell suspensions in complete RPMI-1640 containing $10 \%$ FBS, and monolayer cells were also stained with the FITC-anti-CD4, APC-anti-CD25, PE-anti-Foxp3, and PerCPanti-CD8a antibodies following the above protocol.

The data were analyzed using FlowJo software (Tomy Digital Biology Co., Ltd., Tokyo, Japan). Tregs were defined as $\mathrm{CD} 4^{+} \mathrm{CD} 25^{+} \mathrm{Foxp}^{+}$cells. The proportion of Tregs in the spleen was defined as the percentage of $\mathrm{CD} 25^{+}$Foxp $3^{+}$cells to $\mathrm{CD} 4^{+}$cells in the spleen. The $\mathrm{CD}^{+} /$Treg ratio in the spleen was calculated as follows: Number of $\mathrm{CD}^{+}$cells divided by number of Treg cells in the spleen.

Measurement of TGF- $\beta$ in plasma. Blood from mice was collected into tubes containing EDTA (BD Biosciences) and centrifuged at $1000 \mathrm{x}$ g for $20 \mathrm{~min}$ at $4^{\circ} \mathrm{C}$. The plasma samples were collected into fresh tubes and centrifuged again at $10,000 \mathrm{xg}$ for $10 \mathrm{~min}$ at $4^{\circ} \mathrm{C}$. The supernatant was used to determine the plasma TGF- $\beta 1$ level by a Canine/Mouse/Porcine/Rat TGF- $\beta 1$ Quantikine ELISA kit (R\&D Systems).

Measurement of IFN- $\gamma$ production by spleen cells. Spleen cells $\left(5 \times 10^{6}\right)$ obtained from the mice in the in vivo study were cultured with Meth A cells $\left(5 \times 10^{4}\right)$ pretreated with $50 \mu \mathrm{g} / \mathrm{ml}$ mitomycin-C (MMC) for $45 \mathrm{~min}$. After 2 days, the cell culture supernatants were collected, and the levels of IFN- $\gamma$ were measured using a Mouse IFN-gamma Quantikine ELISA kit (R\&D Systems).

Statistical analysis. Data are presented as means \pm standard error of the mean (SE). Statistical analyses were performed 
A
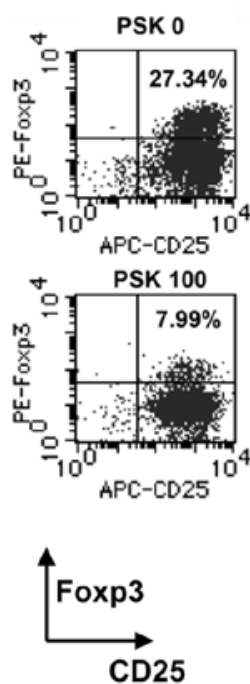

B
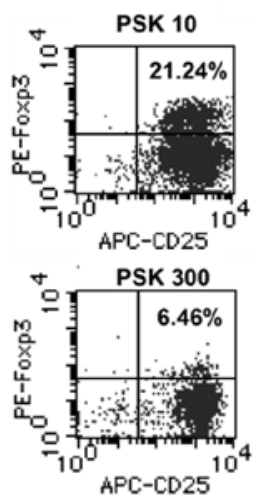

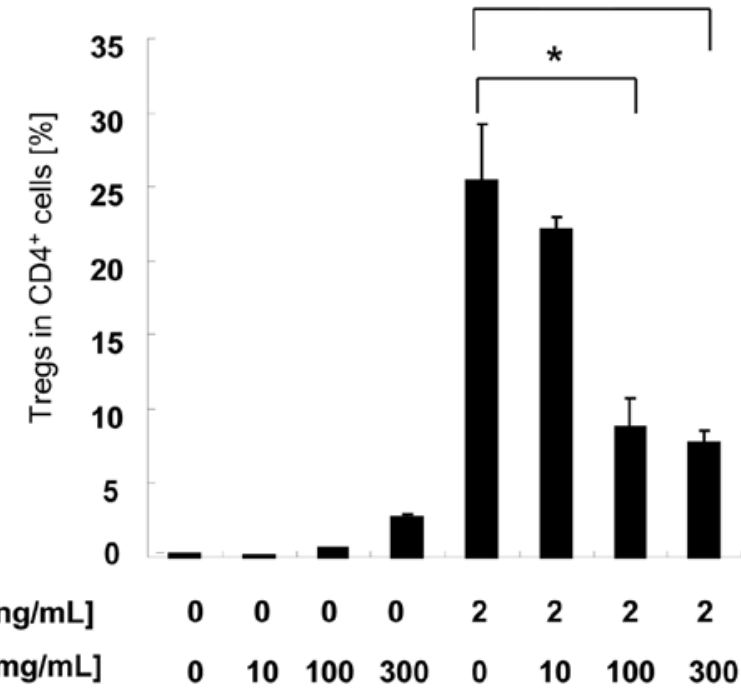

Figure 1. Reduction of the proportion of Tregs by PSK in vitro. Spleens was harvested from normal C57BL/6 mice, and CD4 ${ }^{+} \mathrm{CD} 25^{-} \mathrm{T}$ cells were purified. $\mathrm{CD} 4^{+} \mathrm{CD} 25^{-}$cells were cultured in the presence of $2 \mathrm{ng} / \mathrm{ml}$ recombinant TGF- $\beta$ with or without PSK for 4 days in a $96-w e l l$ plate. After incubation, the proportion of Tregs was analyzed by flow cytometry. (A) Representative plots gated for CD4 ${ }^{+} \mathrm{T}$ cells of one mouse from each group are shown. (B) The percentage of Treg to $\mathrm{CD}^{+}$cells in the individual groups are shown. Data are presented as mean $+\mathrm{SEM}$ ( $\mathrm{n}=3$ wells). Similar results were obtained in two independent experiments. ${ }^{*} \mathrm{P}<0.05$.

using Student's t-test and Mann-Whitney U test. P-values $<0.05$ were considered to indicate statistically significant results.

\section{Results}

PSK reduces the proportion of TGF- $\beta$-induced Tregs in vitro. We first confirmed whether Tregs were induced by TGF- $\beta$ from $\mathrm{CD} 4^{+} \mathrm{CD} 25^{-} \mathrm{T}$ cells by an in vitro conversion assay. After culturing $\mathrm{CD}^{+} \mathrm{CD} 25^{-} \mathrm{T}$ cells for 4 days in the presence of TGF- $\beta$, the proportion (mean $\pm \mathrm{SE}$ ) of $\mathrm{CD}^{2} 5^{+} \mathrm{Foxp} 3^{+}$cells to $\mathrm{CD} 4{ }^{+}$cells was $25.42 \pm 3.83 \%$ (Fig. $1 \mathrm{~B}$ ).

Next, the effect of PSK on Treg conversion was examined. The proportion (mean $\pm \mathrm{SE}$ ) of $\mathrm{CD} 25^{+} \mathrm{Foxp} 3^{+}$cells to $\mathrm{CD} 4^{+}$ cells was $22.18 \pm 0.824 \%$ with $10 \mu \mathrm{g} / \mathrm{ml}$ of PSK, $8.74 \pm 1.98 \%$ with $100 \mu \mathrm{g} / \mathrm{ml}$ of PSK and $7.75 \pm 0.763 \%$ with $300 \mu \mathrm{g} / \mathrm{ml}$ of PSK (Fig. 1B).

These data indicate that PSK reduces the proportion of TGF- $\beta$-induced Tregs in a dose-dependent manner.

Depletion of Tregs suppresses tumor growth in Meth A-bearing mice. To exam whether tumor growth is related to Tregs, BALB/c mice were inoculated subcutaneously with Meth A cells and then received intraperitoneal injections of the antiCD25 antibody to deplete Tregs. In a preliminary study, when BALB/c mice were administered the anti-CD25 antibody, the Tregs were depleted immediately and recovered 7 days after injection (data not shown). Therefore, we administered the antibody once a week. Tumor growth was significantly suppressed by depletion of Tregs (Fig. 2).

The anti-CD25 antibody did not directly affect the growth of Meth A cells in vitro. Therefore, the data of the present study suggest that depletion of Tregs in mice augments the activity of other immune cells and suppresses the growth of Meth A tumor cells in vivo.

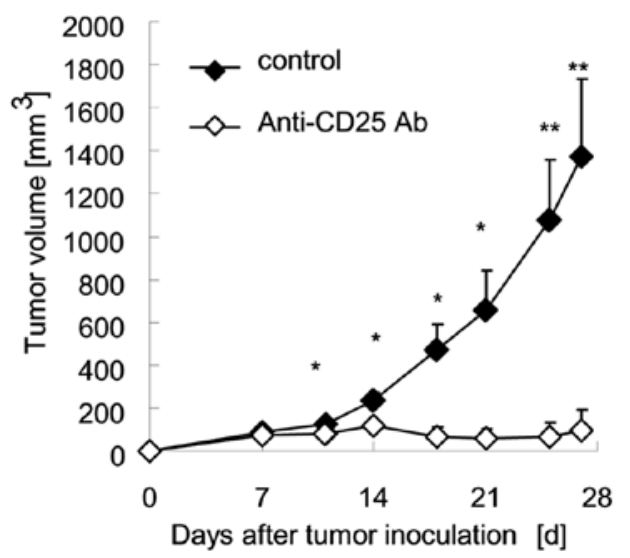

Figure 2. Antitumor effect induced by depletion of Tregs in Meth A-tumorbearing mice. BALB/c mice were inoculated subcutaneously with $1 \times 10^{6}$ Meth A cells on day 0 , and then injected intraperitoneally with the anti-CD25 antibody on days $1,8,15$ and 22 . Tumor volume $\left(\mathrm{mm}^{3}\right)$ was measured from day 7 after tumor inoculation at a frequency of twice per week. Each group consisted of 8 mice. Similar results were obtained in two independent experiments. ${ }^{*} \mathrm{P}<0.05,{ }^{* *} \mathrm{P}<0.01$, vs. control.

PSK suppresses tumor growth in Meth A-bearing mice. We examined the effect of PSK on the growth of Meth A tumors. Tumor growth in mice treated with $50 \mathrm{mg} / \mathrm{kg}$ PSK was significantly suppressed compared to the saline control group (Fig. 3).

PSK reduces the proportion of Tregs and increases the CD8/Treg ratio in Meth A-bearing mice. We next attempted to examine the underlying mechanism by which PSK inhibits tumor growth. Since the growth of Meth A cells in vivo was related to Tregs, we investigated the proportion of Tregs and the $\mathrm{CD}^{+} /$Treg ratio in the spleen of Meth A-bearing mice with or without PSK treatment. Our results showed that the 
A

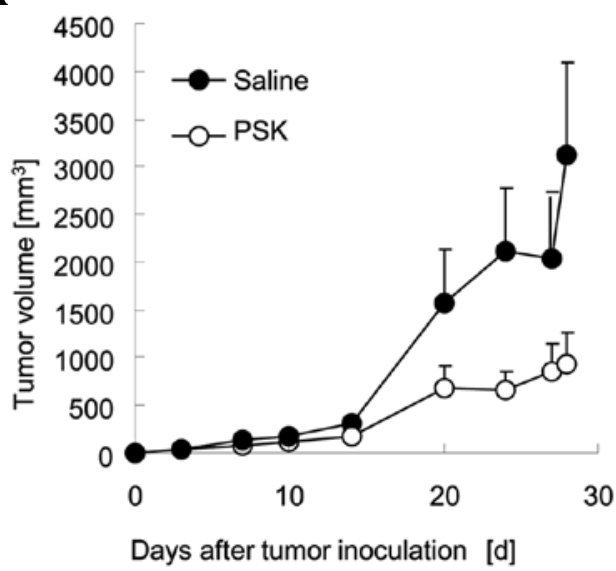

B

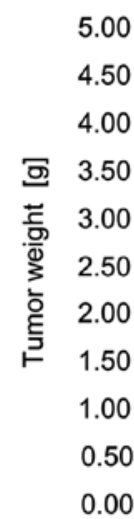

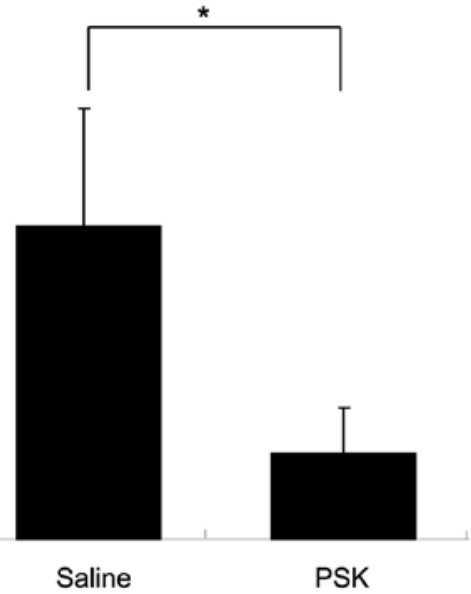

Figure 3. Antitumor effect induced by PSK in Meth A-tumor-bearing mice. BALB/c mice were inoculated subcutaneously with $1 \times 10^{6}$ Meth A cells on day 0 , and injected intraperitoneally with PSK $(50 \mathrm{mg} / \mathrm{kg})$ or saline from day 1 , at a frequency of thrice per week. (A) Changes in tumor volume over time are shown. Tumor volume was measured twice per week. Data are presented as means + SEM ( $\mathrm{n}=8$ mice). (B) Tumor weights (mean + SEM) at 4 weeks after tumor inoculation are shown. Mice were euthanized, and tumor weights were determined. Similar results were obtained in two independent experiments. ${ }^{*}<0.05$, vs. saline.

A
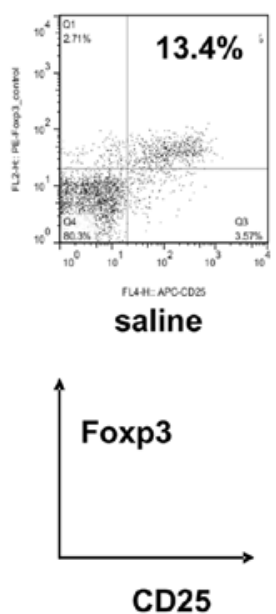

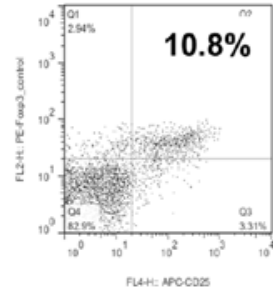

PSK

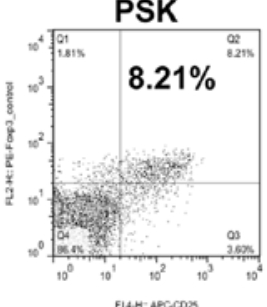

normal
B

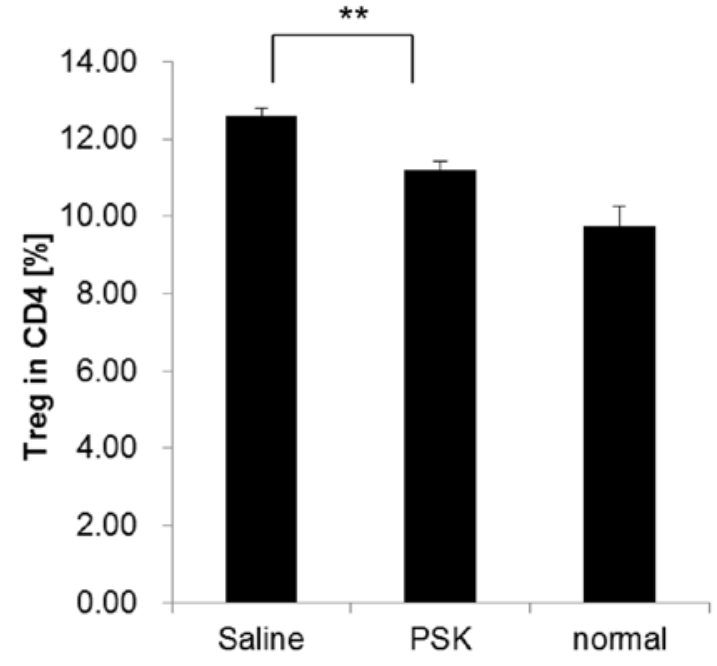

Figure 4. Reduction in the proportion of Tregs by PSK in vivo. BALB/c mice were inoculated subcutaneously with $1 \times 10^{6}$ Meth A cells on day 0 , and then injected intraperitoneally with PSK $(50 \mathrm{mg} / \mathrm{kg})$ or saline from day 1 , at a frequency of thrice per week. Four weeks after tumor inoculation, the spleens were harvested, and the percentage of Tregs to $\mathrm{CD} 4^{+}$cells was determined by flow cytometry. Saline and PSK groups consisted of 8 mice each. The normal group consisted of 4 mice. (A) Representative plots gated for $\mathrm{CD}^{+} \mathrm{T}$ cells of one mouse from each group are shown. Numbers represent the percent of Foxp3 $3^{+} \mathrm{CD} 25^{+}$ cells among CD4 ${ }^{+} \mathrm{T}$ cells. (B) The percentage of Tregs in $\mathrm{CD} 4^{+}$cells (means $+\mathrm{SEM}$ ) of three groups are shown. Similar results were obtained in two independent experiments. ${ }^{* *} \mathrm{P}<0.01$.

proportion of Tregs in the saline control group was significantly higher when compared to the proportion in the normal group, and PSK treatment decreased the proportion of Tregs significantly compared to the saline group (Fig. 4).

In addition, the $\mathrm{CD}^{+} /$Treg ratio in the saline group was significantly lower when compared to this ratio in the normal group, and PSK treatment increased the proportion significantly when compared to the saline group (Fig. 5).

PSK decreases the plasma TGF- $\beta$ levels in the tumorbearing mice. We also measured the plasma TGF- $\beta$ levels in Meth A-bearing mice by ELISA. The concentration of TGF- $\beta$ was $12.4 \mathrm{ng} / \mathrm{ml}$ in the saline group, $6.33 \mathrm{ng} / \mathrm{ml}$ in the PSK group and $3.52 \mathrm{ng} / \mathrm{ml}$ in the normal group. PSK treatment reduced the plasma TGF- $\beta$ level significantly when compared to the level in the saline group (Fig. 6).

These results suggest that the reduction in the blood TGF- $\beta$ concentration by PSK reduces the proportion of Tregs in the spleen and enhances antitumor immunity.

PSK increases IFN- $\gamma$ production by spleen cells in tumorbearing mice. We also examined whether PSK increases tumor-reactive cells in tumor-bearing mice. Spleen cells collected from mice in the in vivo study were cultured with 
A
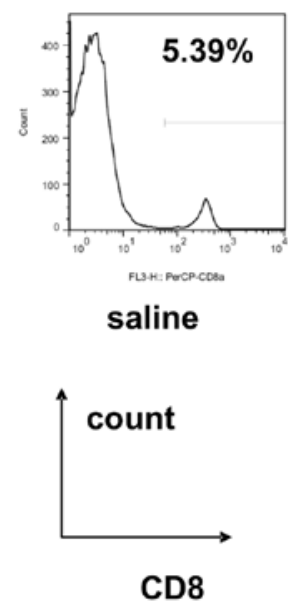

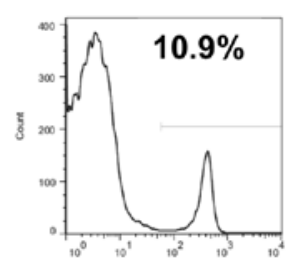

PSK

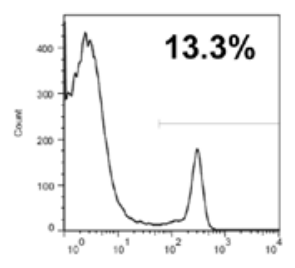

normal
B

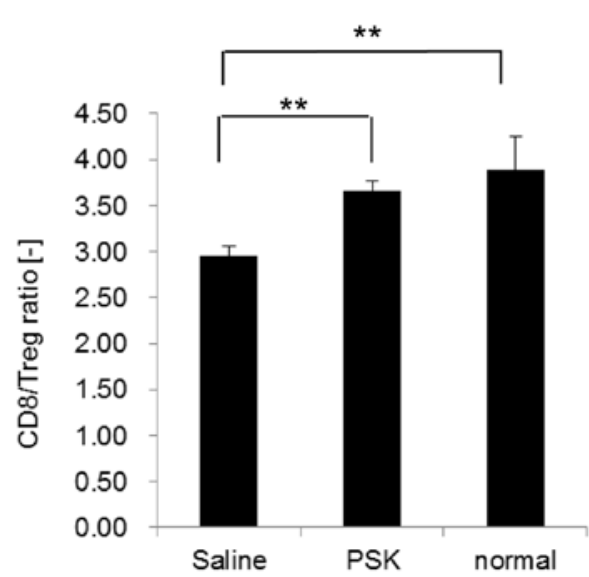

Figure 5. PSK increases the CD8/Treg ratio in tumor-bearing mice. Four weeks after subcutaneous tumor inoculation, the spleens were harvested, and the percentage of $\mathrm{CD}^{+} \mathrm{T}$ cells was determined by flow cytometry. Saline and PSK groups consisted of 8 mice. The normal group consisted of 4 mice. (A) Representative plots of one mouse in each group are shown. Numbers represent the percentage of CD8 ${ }^{+}$cells in spleen cells. (B) CD8/Treg ratios (means + SEM) of three groups are shown. Saline and PSK groups consisted of 8 mice. The normal group consisted of 4 mice. Similar results were obtained in two independent experiments. ${ }^{* *} \mathrm{P}<0.01$.

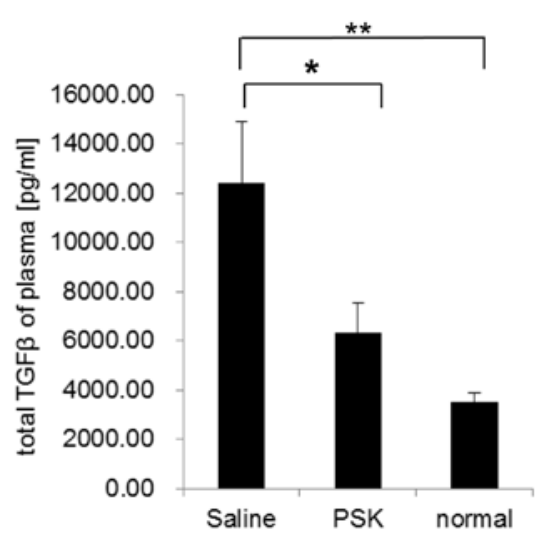

Figure 6. PSK reduces the plasma TGF- $\beta$ level. Four weeks after tumor inoculation, blood was collected from the mice, and plasma TGF- $\beta$ levels were determined by ELISA. Saline and PSK groups consisted of 8 mice. The normal group consisted of 4 mice. ${ }^{*} \mathrm{P}<0.05$.

MMC-treated Meth A in vitro, and the concentrations of IFN- $\gamma$ in the supernatants were measured by ELISA. Spleen cells from PSK-administered mice showed significantly higher IFN- $\gamma$ production when compared to the production in the spleen cells from saline-injected mice (Fig. 7). These results suggest that PSK effectively increases the activity of tumorreactive cells in tumor-bearing mice.

\section{Discussion}

Clinical studies have demonstrated that PSK reduces the proportion of Tregs in the peripheral blood of gastric cancer (19) and colorectal cancer patients (20). Therefore, we attempted to clarify the relationship between PSK and Tregs, and the mechanism by which PSK reduces Tregs, by conducting in vitro and in vivo studies. In the present study, we demonstrated that PSK suppressed the proportion of Tregs in vitro and in vivo. Moreover, we showed the possibility that PSK reduces Tregs through reducing the level of TGF- $\beta$.

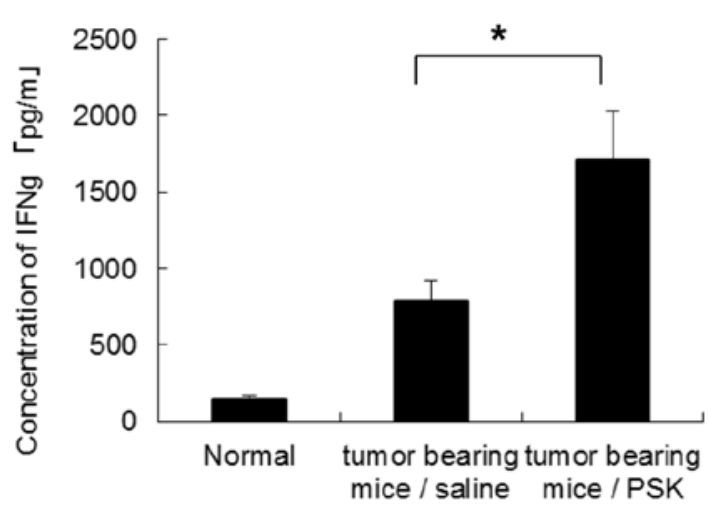

Figure 7. PSK increases IFN- $\gamma$ production by spleen cells. Four weeks after tumor inoculation, the spleens were harvested from mice. Spleen cells were cultured with mitomycin-C-treated Meth A cells for 2 days. The concentrations of IFN- $\gamma$ in the supernatants were determined by ELISA. ${ }^{*} \mathrm{P}<0.05$, vs. tumor-bearing mice/saline.

There are various clinical approaches by which to abolish immunosuppression induced by Tregs $(9,10,21)$, such as depletion of Tregs with anti-CD25 antibodies. Daclizumab, the humanized anti-CD25 antibody, caused long-lasting depletion of Tregs and enhancement of anti-peptide immune responses in a peptide vaccination trial for breast cancer (11). In the present study, growth of Meth A tumor cells in mice was also suppressed by depletion of Tregs with the anti-CD25 antibody. This finding shows that Tregs are absolutely essential for tumor growth. Many reports have shown that the anti-CD25 antibody is useful if administered before grafting of a tumor (21). However, in the present study, the anti-CD25 antibody administered after subcutaneous inoculation of Meth A tumor cells was also effective. Therefore, the Meth A tumor-bearing mouse model may be sensitive to the depletion of Tregs. While therapy targeting Tregs is effective as mentioned above, the suppression of Tregs also produces adverse effects (9) and the anti-CD25 antibody depletes not only Tregs but also effector 
cells (10). Therefore, the timing of antibody administration and the dose have to be considered carefully when Tregs are directly suppressed. On the other hand, since the present study suggests that PSK reduces Tregs probably not by direct action on Tregs but by indirect control via the reduction of TGF- $\beta$, PSK may offer an advantage over other direct depletion methods in terms of fewer adverse effects.

TGF- $\beta$ is known as an immunosuppressive cytokine and has been shown recently to play an important role in inducing Tregs and suppressing the functions of other immune cells via Tregs (22). Plasma TGF- $\beta$ levels and the proportion of Tregs in the spleen were increased in tumor-bearing mice than that in normal mice in the present study. On the other hand, plasma TGF- $\beta$ levels and the proportion of Tregs in tumor-bearing mice administered PSK were not lower than those in normal mice. This result implies that the reduction in TGF- $\beta$ concentration by PSK may reduce the population of TGF- $\beta$-induced Tregs in tumor-bearing host and enhance antitumor immunity.

Moreover, PSK treatment not only decreased the proportion of Tregs, but also increased the proportion of $\mathrm{CD}^{+}$ $\mathrm{T}$ cells and IFN- $\gamma$ production by spleen cells. These results indicate that PSK improves the immunosuppressive condition in tumor-bearing hosts. Lu et al (23) also reported an increase in the number of IFN $\gamma$-secreting tumor-specific $\mathrm{T}$ cells in PSK-treated tumor-bearing mice. However, it remains unclear which immune cells participated in the enhanced antitumor immunity in the present study. We are planning to identify the effector cells using depletion experiments by administering specific antibody to each immune cell type.

Recently, new anticancer immunotherapies have been evaluated in clinical studies (24,25). Cancer vaccines are one of these novel approaches, but their clinical efficacy is not yet sufficient (26). One major reason is that Treg-induced immunosuppressive conditions interfere with cancer vaccine-induced immune responses to cancer. Therefore, it is important to control Tregs in cancer immunotherapies. In a murine osteosarcoma model, administration of the anti-TGF- $\beta$ antibody combined with cancer vaccine therapy suppressed tumor volume and inhibited the accumulation of Tregs, inducing CD8 $T$ cell infiltration in tumor tissues and Treg accumulation in the spleen (27). Therefore, TGF- $\beta$ blockade when combined with cancer vaccine is effective for the reduction of Tregs and is one of the most effective strategies in cancer immunotherapy.

In conclusion, the present study demonstrated that PSK suppressed Tregs in vitro and in vivo. In the future, identifying the effects of PSK on other immune cells would not only elucidate the mechanism of action of PSK, but also confirm the benefit of using PSK in combination with cancer vaccine therapies.

\section{Acknowledgements}

The present study was conducted at Tokyo Women's Medical University, Tokyo, Japan; Ochanomizu University, Tokyo, Japan; and Kureha Corp., Tokyo, Japan.

\section{References}

1. Dunn GP, Old LJ and Schreiber RD: The immunobiology of cancer immunosurveillance and immunoediting. Immunity 21 : 137-148, 2004.
2. Algarra I, Cabrera T and Garrido F: The HLA crossroad in tumor immunology. Hum Immunol 61: 65-73, 2000.

3. Sharma S, Stolina M, Lin Y, Gardner B, Miller PW, Kronenberg M and Dubinett SM: T cell-derived IL-10 promotes lung cancer grow th by suppressing both T cell and APC function. J Immunol 163: 5020-5028, 1999.

4. Lesokhin AM, Hohl TM, Kitano S, Cortez C, HirschhornCymerman D, Avogadri F, Rizzuto GA, Lazarus JJ, Pamer EG, Houghton AN, Merghoub T and Wolchok JD: Monocytic CCR2 ${ }^{+}$ myeloid-derived suppressor cells promote immune escape by limiting activated CD8 T-cell infiltration into the tumor microenvironment. Cancer Res 72: 876-886, 2012.

5. Yamaguchi $\mathrm{T}$ and Sakaguchi S: Regulatory $\mathrm{T}$ cells in immune surveillance and treatment of cancer. Semin Cancer Biol 16: 115-123, 2006.

6. Curiel TJ, Coukos G, Zou L, Alvarez X, Cheng P, Mottram P, Evdemon-Hogan M, Conejo-Garcia JR, Zhang L, Burow M, Zhu Y, Wei S, Kryczek I, Daniel B, Gordon A, Myers L, Lackner A, Disis ML, Knutson KL, Chen L and Zou W: Specific recruitment of regulatory $\mathrm{T}$ cells in ovarian carcinoma fosters immune privilege and predicts reduced survival. Nat Med 10: 942-949, 2004.

7. Woo EY, Yeh H, Chu CS, Schlienger K, Carroll RG, Riley JL, Kaiser LR and June CH: Cutting edge: regulatory T cells from lung cancer patients directly inhibit autologous $\mathrm{T}$ cell proliferation. J Immunol 168: 4272-4276, 2001.

8. Suzuki H, Chikazawa N, Tasaka T, Wada J, Yamasaki A, Kitaura Y, Sozaki M, Tanaka M, Onishi H, Morisaki T and Katano M: Intratumoral CD8 ${ }^{+} \mathrm{T} / \mathrm{FOXP} 3{ }^{+}$cell ratio is a predictive marker for survival in patients with colorectal cancer. Cancer Immunol Immunother 59: 653-661, 2010.

9. Maker AV, Attia P and Rosenberg SA: Analysis of the cellular mechanism of antitumor responses and autoimmunity in patients treated with CTLA-4 blockade. J Immunol 175: 7746-7754, 2005.

10. Jacobs JF, Punt CJ, Lesterhuis WJ, Sutmuller RP, Brouwer HM, Scharenborg NM, Klasen IS, Hilbrands LB, Figdor CG, de Vries IJ and Adema GJ: Dendritic cell vaccination in combination with anti-CD25 monoclonal antibody treatment: a phase I/II study in metastatic melanoma patients. Clin Cancer Res 16: 5067-5078, 2010.

11. Rech AJ, Mick R, Martin S, Recio A, Aqui NA, Powell DJ Jr, Colligon TA, Trosko JA, Leinbach LI, Pletcher $\mathrm{CH}$, Tweed CK, DeMichele A, Fox KR, Domchek SM, Riley JL and Vonderheide RH: CD25 blockade depletes and selectively reprograms regulatory $\mathrm{T}$ cells in concert with immunotherapy in cancer patients. Sci Transl Med 4: 134ra62, 2012.

12. Chen W, Jin W, Hardegen N, Lei KJ, Li L, Marinos N, McGrady G and Wahl SM: Conversion of peripheral $\mathrm{CD} 4^{+} \mathrm{CD} 25^{-}$naive $\mathrm{T}$ cells to $\mathrm{CD} 4{ }^{+} \mathrm{CD} 25^{+}$regulatory $\mathrm{T}$ cells by TGF- $\beta$ induction of transcription factor Foxp3. J Exp Med 198: 1875-1886, 2003.

13. Huber S, Stahl FR, Schrader J, Lüth S, Presser K, Carambia A, Flavell RA, Werner S, Blessing M, Herkel J and Schramm C: Activin a promotes the TGF- $\beta$-induced conversion of $\mathrm{CD} 4{ }^{+} \mathrm{CD} 25$ $\mathrm{T}$ cells into Foxp3 $3^{+}$induced regulatory T cells. J Immunol 182: 4633-4640, 2009.

14. Hirahara N, Edamatsu T, Fujieda A, Fujioka M, Wada T and Tajima Y: Protein-bound polysaccharide-K (PSK) induces apoptosis via p38 mitogen-activated protein kinase pathway in promyelomonocytic leukemia HL-60 cells. Anticancer Res 32: 2631-2638, 2012.

15. Sakagami H, Sugaya K, Utsumi A, Fujinaga S, Sato T and Takeda M: Stimulation by PSK of interleukin-1 production by human peripheral blood mononuclear cells. Anticancer Res 13: 671-675, 1993.

16. Kato M, Hirose K, Hakozaki M, Ohno M, Saito Y, Izutani R, Noguchi J, Hori Y, Okumoto S, Kuroda D, et al: Induction of gene expression for immunomodulating cytokines in peripheral blood mononuclear cells in response to orally administered PSK, an immunomodulating protein-bound polysaccharide. Cancer Immunol Immunother 40: 152-156, 1995.

17. Matsunaga K, Hosokawa A, Oohara M, Sugita N, Harada M and Nomoto K: Direct action of a protein-bound polysaccharide, PSK, on transforming growth factor-beta. Immunopharmacology 40: 219-230, 1998.

18. Harada M, Matsunaga K, Oguchi Y, Iijima H, Tamada K, Abe K, Takenoyama M, Ito O, Kimura G and Nomoto K: Oral administration of PSK can improve the impaired anti-tumor CD4 ${ }^{+} \mathrm{T}$-cell response in gut-associated lymphoid tissue (GALT) of specificpathogen-free mice. Int J Cancer 70: 362-372, 1997. 
19. Yoshikawa K, Shimada M, Kurita N, Sato H, Iwata T, Nishioka M Morimoto S, Miyatani T, Komatsu M and And RN: The effect of polysaccharide $\mathrm{k}$ with $\mathrm{s}-1$ based chemotherapy in advanced gastric cancer. Hepatogastroenterology 60: 1387-1390, 2013.

20. Yoshino S, Yoshimura K, Suzuki N, Iida M, Yoshida S, Maeda Y Maeda K, Hazama S and Oka M: Immunoregulatory effects of PSK on the Th1/Th2 balance and regulatory T-cells in patients with colorectal cancer. Gan To Kagaku Ryoho 37: 2234-2236, 2010 (In Japanese).

21. Onizuka S, Tawara I, Shimizu J, Sakaguchi S, Fujita T and Nakayama E: Tumor rejection by in vivo administration of anti-CD25 (interleukin-2 receptor $\alpha$ ) monoclonal antibody. Cancer Res 59: 3128-3133, 1999.

22. Shen E, Zhao K, Wu C and Yang B: The suppressive effect of $\mathrm{CD} 25^{+}$Treg cells on Th1 differentiation requires cell-cell contact partially via TGF- $\beta$ production. Cell Biol Int 35: 705-712, 2011.

23. Lu H, Yang Y, Gad E, Wenner CA, Chang A, Larson ER, Dang Y, Martzen M, Standish LJ and Disis ML: Polysaccharide krestin is a novel TLR2 agonist that mediates inhibition of tumor growth via stimulation of CD8 T cells and NK cells. Clin Cancer Res 17: 67-76, 2011.
24. Aarntzen EH, De Vries IJ, Lesterhuis WJ, Schuurhuis D, Jacobs JF, Bol K, Schreibelt G, Mus R, De Wilt JH, Haanen JB, Schadendorf D, Croockewit A, Blokx WA, Van Rossum MM, Kwok WW, Adema GJ, Punt CJ and Figdor CG: Targeting CD4 ${ }^{+}$ T-helper cells improves the induction of antitumor responses in dendritic cell-based vaccination. Cancer Res 73: 19-29, 2013.

25. Sawada Y, Yoshikawa T, Nobuoka D, Shirakawa H, Kuronuma T, Motomura Y, Mizuno S, Ishii H, Nakachi K, Konishi M, Nakagohri T, Takahashi S, Gotohda N, Takayama T, Yamao K, Uesaka K, Furuse J, Kinoshita T and Nakatsura T: Phase I trial of a glypican-3-derived peptide vaccine for advanced hepatocellular carcinoma: immunologic evidence and potential for improving overall survival. Clin Cancer Res 18: 3686-3696, 2012.

26 Rosenberg SA, Yang JC and Restifo NP: Cancer immunotherapy: moving beyond current vaccines. Nat Med 10: 909-915, 2004.

27. Kawano M, Itonaga I, Iwasaki T, Tsuchiya $\mathrm{H}$ and Tsumura $\mathrm{H}$ : Anti-TGF- $\beta$ antibody combined with dendritic cells produce antitumor effects in osteosarcoma. Clin Orthop Relat Res 470: 2288-2294, 2012. 